\title{
Teacher Competences for Active Learning in Engineering Education
}

\author{
Renato Martins Neves ${ }^{1, *(\mathbb{D}}$, Rui M. Lima ${ }^{2}\left(\mathbb{D}\right.$ and Diana Mesquita ${ }^{3}$ \\ 1 Graduate Program in Civil Engineering (PPGEC), Federal University of Pará (UFPA), Belém 66075-110, Brazil \\ 2 Algoritmi Center, Department of Production and Systems, School of Engineering, University of Minho, \\ 4800-058 Guimarães, Portugal; rml@dps.uminho.pt \\ 3 Research Centre for Human Development (CEDH), Faculty of Education and Psychology, \\ Portuguese Catholic University, 4169-005 Porto, Portugal; dmesquita@ucp.pt \\ * Correspondence: neves@ufpa.br
}

Citation: Neves, R.M.; Lima, R.M.; Mesquita, D. Teacher Competences for Active Learning in Engineering Education. Sustainability 2021, 13, 9231. https://doi.org/10.3390/ su13169231

Academic Editor: Barbara Motyl

Received: 23 July 2021

Accepted: 11 August 2021

Published: 17 August 2021

Publisher's Note: MDPI stays neutral with regard to jurisdictional claims in published maps and institutional affiliations.

Copyright: (c) 2021 by the authors. Licensee MDPI, Basel, Switzerland. This article is an open access article distributed under the terms and conditions of the Creative Commons Attribution (CC BY) license (https:/ / creativecommons.org/licenses/by/ $4.0 /)$.

\begin{abstract}
The implementation of active learning strategies in engineering education still encounters barriers when facing conventional teaching-learning practices. This work aims to contribute to the discussion on teachers' pedagogical competences required for active learning. This contribution is developed from the perceptions of 205 engineering teachers of Brazilian higher education institutions, centered on significant teaching competences necessary for teachers of engineering courses and how to develop them in the active learning context. The results show that essential competences identified by the participants are (I) teamwork (teachers' cooperation); (II) teacher-student relationships (empathy); (III) feedback about students' performance throughout the learning process; (IV) information and communication technology (ICT) competences; (V) selecting and adapting the teaching-learning methodologies to the class context; and (VI) creativity. A complementary logistic regression model suggested that female Ph.D. full-time teachers are more likely to employ active learning. Differences in active learning adoption among Brazilian regions were also captured by the model. The identified competences are essential for the sustainability of the innovation of teaching practices in the context of active learning, which may be used to inform more effective professional training of engineering teachers in the current globalized scenario.
\end{abstract}

Keywords: active learning; project-based learning; problem-based learning; sustainable engineering education; pedagogical competences; teachers' training; professional development; Brazilian higher education

\section{Introduction}

The 21st-century globalization and the corresponding disruptive global changes have reinforced the need for new educational models in which students are more participative and encouraged to find solutions to real problems [1], contributing to a transformation of the engineering curriculum.

The educational community has been investigating alternative teaching-learning processes concerning active methods, aiming to develop technical and transversal competences in future engineers. Thus, several proposals for teaching-learning strategies have emerged worldwide in Engineering Education, as problem and project-based learning (PBL), widely recognized due to the positive results [2-4]. Additionally, Peer Instruction, flipped classroom, team-based learning (TBL), and other active learning strategies enable positive educational outcomes, such as increased student engagement and performance [5].

These innovative teaching-learning approaches are challenging for teachers and students, requiring close collaboration between all players, effective communication, and the development of a sense of autonomy, trust, and resilience [6]. This idea implies leading teachers to rethink the background of their teaching strategies. It takes importance by 
analyzing the crucial role of the teacher as facilitator in the active learning process [7], considering the substantial impact on students' learning.

In the Brazilian context, Engineering Education encountered resistance from teachers to change the teaching approaches [8], particularly when the Ministry of Education (MEC) implemented the National Curriculum Guidelines (Diretrizes Curriculares NacionaisDCN). According to the DCN, engineering professionals demand technical and transversal competences developed by implementing active learning within the curricula. However, such processes are more challenging to implement than the conventional ones due to failures in engineering teachers' pedagogic training, creating barriers to designing and implementing active learning approaches.

This problem leads Brazilian Higher Education Institutions (HEI) to revise the training of their engineering teachers, with adaptations to new teaching-learning methods, occurring in both voluntary and mandatory ways. In one way or another, Brazilian HEI and engineering teachers are starting to feel obliged to leave their comfort zone in which conventional teaching has been hiding [9]. Despite the need for teachers' professional development, a study developed by Oliveira et al. [10] presented a systematic survey of articles published between 2007 and 2015 in the Brazilian Engineering Education Congress (translated from Congresso Brasileiro de Educação em Engenharia-COBENGE), which identified few publications concerning teachers' pedagogic training to use active learning strategies.

Once there is this significant research gap, this study sought to investigate the perception of 205 engineering professors in Brazil about the new teacher role in developing active learning and the required teacher competences to implement them in the classroom. A detailed survey allowed us to examine both quantitative (closed-ended questions) and qualitative (open-ended questions) data, complemented by a logistic regression model to identify the likelihood profile of active learning users. This paper intends to contribute to the literature on engineering teachers' pedagogical training by identifying the necessary competencies that will allow informed decisions for sustainable active learning training in Engineering Education.

\section{Conceptual Framework}

\subsection{Active Learning}

According to Prince [11], a tautological consensus on active learning is not possible because there are several universally accepted definitions, since different authors interpret some terms differently. Based on this, we understand that active learning engages and challenges students to use real and imaginary situations, demanding higher-order thinking skills such as analysis, synthesis, and evaluation. In active learning environments, students are involved in research, action, imagination, invention, interaction, hypothesis, and personal reflection [2]. According to Bonwell and Eison [12], active learning can be any instructional method that involves students in the learning process. In short, active learning requires students to perform meaningful learning activities and reflect upon what and how they are learning.

Therefore, "active learning" is a term assigned to a set of pedagogical practices that address the issue of student learning from a different perspective of conventional learning techniques, such as rhetorical classes, where the teacher expects to "teach" and the student to "learn". In active learning environments, the student needs to be actively engaged in building knowledge, focusing on the proposed goals and seeking the knowledge necessary in a proactive way [13]. Then, active learning is the teaching-learning process in which the teacher is no longer mainly a transmitter of knowledge, and the student is no more a merely passive accumulator of knowledge. During the active learning process, the teacher induces the student to be proactive, developing or enhancing their skills. According to Pereira et al. [14], the teacher leaves the exclusivity of intellectual activity and the representation of the textbook as exclusive sources of knowledge in the classroom. 
According to Diesel et al. [15], the essence of active learning is not something new. The underlying principles of active learning based on known theoretical approaches [16] such as Paulo Freire, John Dewey, and others may be synthesized as follows:

- Student as the focus of teaching-learning process: students have more control and an effective participation in the process, requiring multiple mental actions and constructions.

- Students' autonomy: stimulating an autonomous posture increases decision-making freedom at different levels.

- Connect to real situations: correlate theoretical knowledge to practical applications, prioritizing alternative solutions to real (or realistic) problems.

- Students' teamwork: interactions among students encourage critical reflection about the proposed problem, besides improving the argument and communication competences.

- Innovation: renew/invent active methods, provoking creativity among students.

- Teacher: mediator, facilitator, activator, who provokes, challenges, and promotes conditions for the student's development without compromising its autonomy.

These principles are the core of several active learning strategies, including case studies, laboratories, teamwork activities, simulations, problem and project-based learning (PBL), Peer Instruction, flipped classroom, and games, among others. For the use of such methodologies, the teacher's competences should be developed for adequately planning and coordinating the learning activities, once it demands for usually non-developed pedagogical competences by engineering educators. In the context of active learning in Engineering Education, problem and project-based learning are two of the most common approaches, and highly relevant whenever addressing the sustainable development goals [17], sustainability issues [18-21] and inclusion [22,23]. Project-based learning allows students to naturally explore some of the characteristics of engineering, such as creation, design, development, implementation, operation, interdisciplinarity, teamwork, communication, stakeholder management, dealing with uncertainties and making decisions, using technical knowledge, empirical knowledge, heuristics, and both a strong sense of scientific rigor and care for social issues [24-27].

\subsection{Teachers' Competences}

According to Guasch et al. [28], competence can be a complex system of actions that include knowledge, skills, and attitudes required to solve a problem. In this sense, active learning approaches must support the new educational challenges [2,3], and teachers must develop educational competences [29-39]. Table 1 presents a list of ten expected competences of teachers identified in several studies. The scope of these competences shows how demanding and complex teaching practice is, as teachers must be able to plan and design the teaching and learning process, work collaboratively, and, additionally, be able to communicate effectively both in oral and written ways, among others.

The COVID-19 pandemic has pushed teachers from different countries to reinvent themselves due to remote teaching (and learning) at home. According to Guasch et al. [28], an overnight change requires new and practical teaching competences. The challenges that actual teachers face closely relate to the particularities of online interaction and communication. König et al. [40] emphasizes the need to foment the development of information and communication technology (ICT) competences, which gained a higher relevance for remote teaching and learning reality. 
Table 1. Expected teachers' competences.

\begin{tabular}{|c|c|c|c|c|c|c|c|c|c|c|c|c|c|}
\hline Competences & 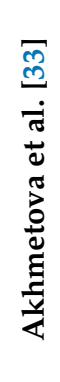 & 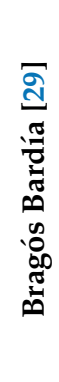 & 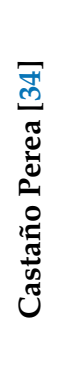 & 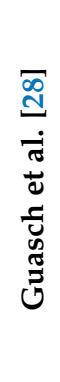 & 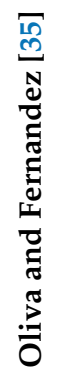 & 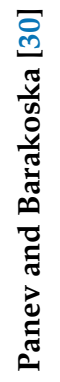 & 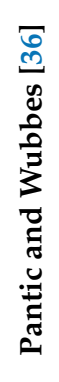 & 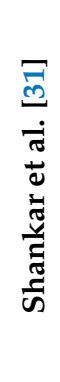 & 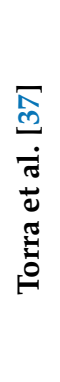 & $\begin{array}{l}\Xi \\
0 \\
0 \\
W \\
\pm \\
\vdots \\
\end{array}$ & $\begin{array}{l}\infty \\
\stackrel{\infty}{0} \\
\stackrel{\pi}{\pi} \\
\stackrel{0}{0} \\
\stackrel{0}{\overline{0}}\end{array}$ & 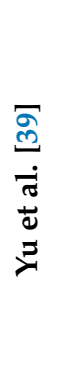 & $\begin{array}{l}\sigma \\
\widetilde{\Xi} \\
\text { స̃ } \\
\text { స̃ } \\
\text { N }\end{array}$ \\
\hline $\begin{array}{l}\text { Planning and design of the } \\
\text { teaching-learning process }\end{array}$ & & $X$ & $x$ & $\mathrm{X}$ & & $X$ & & $x$ & $X$ & & $x$ & $x$ & $\mathrm{X}$ \\
\hline Interpersonal & & $\mathrm{X}$ & & $x$ & & & & & $x$ & & $x$ & $x$ & \\
\hline Technical instruction & & $\mathrm{X}$ & & $x$ & & & & $x$ & & & & $x$ & \\
\hline Technological domain & & $x$ & & $x$ & $x$ & $x$ & & & $x$ & $x$ & & & $\mathrm{x}$ \\
\hline Academic management & & & & $x$ & $x$ & & & & $x$ & $x$ & $x$ & & $x$ \\
\hline $\begin{array}{l}\text { Self-assessment and } \\
\text { professional development }\end{array}$ & & & & & $x$ & & $\mathrm{X}$ & $\mathrm{X}$ & & & $\mathrm{X}$ & & $\mathrm{X}$ \\
\hline Autonomous learning & & $x$ & & & & $x$ & & & & & & & \\
\hline Teamwork & & $x$ & $x$ & & $x$ & & & & $\mathrm{X}$ & $x$ & & $x$ & $\mathrm{x}$ \\
\hline $\begin{array}{l}\text { Oral and written } \\
\text { communication }\end{array}$ & $x$ & $x$ & $x$ & & & $x$ & & & $x$ & $x$ & $x$ & & $x$ \\
\hline $\begin{array}{l}\text { Entrepreneurship and } \\
\text { innovation }\end{array}$ & & $\mathrm{X}$ & $\mathrm{X}$ & & & & & & $\mathrm{X}$ & & & $\mathrm{X}$ & \\
\hline
\end{tabular}

\subsection{New Context in Brazilian Engineering Education}

In the context of rapid social and economic changes in the 21st century, the profile of engineering professionals must be rethought, namely by reinforcing [41] the relationship between theory and practice in the context of Engineering Education. In fact, there is a time lag between learning essential basic sciences and professional subjects, i.e., between the sciences' theory and its application to practical problems. Neves [42] also states that 21st-century engineers will require less mastery of the content of their expertise areas and much more a higher capacity to solve interdisciplinary problems, besides decisionmaking, teamwork, and communication. According to these authors, undergraduate programs should contribute to developing professionals capable of facing the current scenario's challenges. Therefore, engineering egresses must be flexible, adaptable, creative, and critical.

Some studies corroborate the need to include engineering projects in the first years and activities that enable students to simultaneously develop technical and transversal competences $[2,3,43]$. Thus, this new challenge requires the teachers to be the key players to operate the active learning and to identify the new necessary competences for its viability. For Vasconcelos [44], pedagogical competence involves a new teacher attitude in the face of the pedagogical act, a new role for the teacher, with higher levels of commitment and understanding, and mastery of techniques and methods.

Currently, the Brazilian engineering programs require that teachers have a level of qualification and technical knowledge in their respective subject areas, lacking didactic and pedagogical competences. In many cases, teachers are limited to passing their knowledge and own professional experiences. Within the new active learning context, some faculty members have become aware of their new role by seeking pedagogical practice qualifications by themselves. As Masseto [45] states, the teacher's pedagogical competence can be an educator whose mission is to collaborate [24] effectively so that their students can develop higher level and diverse competences, which is a job that needs pedagogical competences.

The same author portrays most of the actual Brazilian HEI teaching-learning process results in unsuitable conditions-as expressive scholar evasion, low academic performance, and career unsatisfaction. Therefore, the teacher-student relationship should be redesigned, 
based on the teachers acting more as facilitators and students being more autonomous. As an agent of facilitation, the teacher enables students to access the content and the practical activities by their ways and perceptions-reaching a unique goal in multiple and adapted ways [9]. Zabalza [9] defines "double competence" as when the teacher simultaneously applies technical and pedagogical competences.

Goldberg and Sommerville [6] reinforce the need to develop technical competences and simultaneously develop competences related to teaching. This challenge requires the teacher to be clear about what learning means, develop knowledge on active learning, understand how learning processes occur in higher education, and understand the educational processes for developing efficient professionals to achieve the expected society goals.

\section{Methods}

This study is based on a questionnaire survey [46] lead by the following research questions: What are the main pedagogical teacher competences for active learning in Brazilian engineering institutions? How do engineering teachers promote active learning contexts? This study was developed in five stages: (I) Literature review; (II) Questionnaire elaboration; (III) Pre-test of the Questionnaire; (IV) Questionnaire application; and (V) Data analysis.

The first stage established the theoretical foundation to understand and compile teacher competences and active learning interfaces. Different sources contributed, such as books, articles, dissertations, and theses. The systematization of the collected information (Table 1) became crucial for elaborating the questionnaire during the second stage. In this second stage, we created the questionnaire to understand the teacher's profile in active learning contexts according to teachers' perceptions. This questionnaire was developed on the Google Forms platform, and the results were organized in electronic spreadsheets. The questionnaire described in Appendix A consist of four sections: characterization of the participants; active learning; teacher competences; and a final section with openended questions to collect suggestions from the participants. The four sections included a total of twenty-five questions, with thirteen closed-ended questions and twelve openended questions.

The third stage, which consisted of the questionnaire pre-test, was carried out by sending the form to four specialists in the Engineering Education field for reviewing the wording or conceptual flaws, including or excluding questions, and checking the clarity of the items. After interaction with the experts, the questionnaire was revised based on their suggestions and recommendations.

Then, during the fourth stage, the questionnaire was sent to the engineering teachers who are members of the Brazilian Association of Engineering Education (translated from Associação Brasileira de Educação em Engenharia-ABENGE). It is important to note that this work was conducted during the 2016 Brazilian Engineering Education Congress (COBENGE), aiming at raising awareness and motivate teachers to answer the forms. There were 763 names in the ABENGE database, including faculty members, students, and staff, which turned into 517 observations - after the database was filtered to only teachers. From the target sample $(n=517), 259$ forms were returned, and 205 were considered complete and valid. The calculation of the population size follows Cleff's [47] formulae to finite samples at a 95\% level of confidence, implying a minimum of 186 responses, which was reached (205 final observations).

The fifth and final stage, the data analysis, was carried out by triangulation and synthesis of information, comparing the empirical results with the literature to support data analysis. We employed a logistic regression model (Table 2) to assess whether there are characteristics that may suggest a higher likelihood for implementing active learning approaches. This technique precedes a binary dependent variable-which was the use or not of active learning approaches. The regressors comprised gender, age, instruction, teaching experience, workload, and HEI region of the respondents, assessed by their odds ratio. The output analyses involved the Wald test at a 95\% level of significance. Analyses of 
chi-square omnibus, Nagelkerke $\mathrm{R}^{2}$, and Hosmer and Lemeshow tests verified the model reliability [47]. The stepwise backward LR function was applied to optimize regressor interactions in exploratory models [48].

Table 2. Logistic regression set up.

\begin{tabular}{|c|c|c|c|}
\hline Variable & Label & Code & Variable Type \\
\hline \multirow[t]{2}{*}{ Active learning user } & No & 0 & Dichotomic \\
\hline & Yes & 1 & \\
\hline \multirow[t]{2}{*}{ Gender } & Male & 0 & Dichotomic \\
\hline & Female & 1 & \\
\hline \multirow{4}{*}{ Age } & Under 30 years old & 1 & Categorical \\
\hline & 31 to 40 years old & 2 & \\
\hline & 41 to 50 years old & 3 & \\
\hline & Older than 60 years old & 4 & \\
\hline \multirow[t]{3}{*}{ Instruction } & Bachelor & 1 & Categorical \\
\hline & Master's degree & 2 & \\
\hline & Doctorate & 3 & \\
\hline Experience & Years of teaching activity & - & Continuous \\
\hline \multirow[t]{4}{*}{ Workload } & Hourly earner & 1 & Categorical \\
\hline & Partial time & 2 & \\
\hline & Full time but not exclusive & 3 & \\
\hline & Full time and exclusive & 4 & \\
\hline \multirow[t]{5}{*}{ HEI region } & Southern Brazil & 1 & Categorical \\
\hline & South-eastern Brazil & 2 & \\
\hline & Middle-Western Brazil & 3 & \\
\hline & North-eastern Brazil & 4 & \\
\hline & Northern Brazil & 5 & \\
\hline
\end{tabular}

\section{Respondents' Profile}

The online questionnaire form was sent to participants of COBENGE based on the following conditions: (I) teachers of engineering courses; (II) being currently teaching. Among the respondents, the majority were male (69.3\%). As shown in Table 3, the age distribution indicated the predominance of educators between 30 and 60 years old, inducing a certain degree of maturity in the sample.

Table 3. Age groups of respondents.

\begin{tabular}{cc}
\hline Age Group & Percentage (\%) \\
\hline Under 30 years old & 5.1 \\
30 to 40 years old & 26.0 \\
41 to 50 years old & 28.1 \\
51 to 60 years old & 30.0 \\
Older than 60 years old & 10.8 \\
\hline
\end{tabular}

To facilitate the grouping of teachers' qualification areas (Table 4), we adopted the Coordination for the Improvement of Higher Education Personnel (translated from Coordenação de Aperfeiçoamento de Pessoal de Nível Superior-CAPES) criterion, the designated governmental organization for qualification in Brazil. Thus, we noted an intense concentration of teaching from Engineering $(75 \%)$ and Exact and Earth Sciences $(16.60 \%)$ areas teaching in engineering courses, which is predictable. The presence of teachers from other areas is marginal, highlighting the technicist aspect of Engineering Education. 
Table 4. Teachers' formation area according to CAPES degrees of qualification.

\begin{tabular}{ccccc}
\hline Knowledge Area & $\begin{array}{c}\text { University } \\
\text { Graduate }\end{array}$ & $\begin{array}{c}\text { Master's } \\
\text { Degree }\end{array}$ & Doctorate & Post-Doctoral \\
\hline Engineering & 74.14 & 66.00 & 46.83 & 11.70 \\
Exact and Earth Sciences & 16.60 & 13.65 & 10.24 & 2.93 \\
Applied Social Sciences & 4.39 & 2.40 & - & 1.46 \\
Human and Agrarian sciences & 1.46 & 8.20 & 7.31 & - \\
Linguistics, Letters, and Arts & 0.97 & - & - & - \\
Health and Biological Sciences & 0.50 & 0.50 & 0.5 & - \\
Other & - & 8.78 & 35.12 & \\
\hline
\end{tabular}

Concerning the teachers' qualifications when entering the teaching career (Table 5), we note that only $22.7 \%$ initiated their academic career already with a doctorate. It indicates that after entering the teaching career, teachers will continue developing their core scientific qualifications, and, simultaneously, their pedagogical competences, which are concomitantly crucial for developing and conducting teaching-learning processes.

Table 5. Teachers' academic qualification when entering the teaching career.

\begin{tabular}{cc}
\hline Formation & Percentage (\%) \\
\hline Bachelor & 31.5 \\
Master's degree & 45.8 \\
Doctorate & 22.7 \\
\hline
\end{tabular}

Regarding the teaching experience, Table 6 shows that most of the respondents have up to 15 years of teaching experience. It demonstrates the importance of investing in pedagogical training for teachers at the beginning of their academic career, intending to support them in seeking the best teaching-learning competences. Investing in recently admitted teachers to adopting active learning practices may create a movement for transformation.

Table 6. Participants' teaching practice time.

\begin{tabular}{cc}
\hline Experience (Years) & Percentage (\%) \\
\hline 0 to 5 & 26.34 \\
6 to 10 & 18.05 \\
11 to 15 & 13.17 \\
16 to 20 & 12.20 \\
21 to 25 & 7.32 \\
26 to 30 & 4.88 \\
31 to 35 & 5.85 \\
36 to 40 & 2.44 \\
41 to 45 & 1.95 \\
46 to 50 & 0.98 \\
Did not answer & 6.83 \\
\hline
\end{tabular}

As shown in Table 7, almost half of the respondents have the exclusive and full-time dedication to academic activities, implying commitment to teaching, researching, and mentoring in Brazilian HEI. It emphasizes the need for teachers' professional development, introducing new teaching-learning methods and periodic training.

Table 7. Distribution of respondents' workload.

\begin{tabular}{cc}
\hline Work Regime Dedication & Percentage (\%) \\
\hline Full time and exclusive & 46.5 \\
Full time but not exclusive $(40 \mathrm{~h})$ & 24.0 \\
Partial time $(20 \mathrm{~h})$ & 18.0 \\
Hourly wage earner & 11.5 \\
\hline
\end{tabular}


Table 8 indicates that most respondents are in South-eastern Brazil. It was possible to verify a concentration of respondents in regions close to the largest cities of Brazil, such as São Paulo and Rio de Janeiro, revealing asymmetries in the regional distribution of teachers interested in the Engineering Education thematic.

Table 8. Regional distribution of respondents.

\begin{tabular}{cc}
\hline Teaching Location & Percentage (\%) \\
\hline South-eastern & 44.88 \\
Southern & 31.71 \\
North-eastern & 9.27 \\
Northern & 7.32 \\
Midwestern & 2.44 \\
Did not answer & 4.39 \\
\hline
\end{tabular}

\section{Results and Discussion}

We present below the results by the following sequence: teaching practice, active learning, and teachers' competences.

\subsection{Teaching Practice}

Regarding the teacher practice (Table 9), approximately $66 \%$ of respondents said they had some type of didactic-pedagogical training in the past three years. Among the types of training presented in the questionnaire, teaching methodologies occurred in a significantly high percentage $(85.1 \%)$. With lower percentages, participants referred training related to assessment processes, planning of teaching-learning processes, and utilization of ICT in the teaching and learning processes. These results show that teachers look for pedagogical training, for updating the competences needed to deal with new educational paradigms (such as active learning and ICT in education). Additionally, it reflects a transformation in higher education with teacher becoming aware of the need to improve their teaching competences.

Table 9. Type of teaching training carried out by the participants.

\begin{tabular}{cc}
\hline Type of Training Carried Out & Percentage (\%) \\
\hline Teaching-learning methodologies & 85.1 \\
Educational assessment processes & 48.5 \\
Didactic-pedagogical planning & 40.3 \\
Use of ICT in teaching-learning & 38.8 \\
\hline
\end{tabular}

The proportion of teachers who answered had not participated in any training experience $(34 \%)$ justified that the Brazilian HEI did not offer any training related to didacticpedagogical practices $(60.3 \%)$ or that they did not have the time to participate in the events held $(30.9 \%)$; however, they emphasized the importance of teaching training to facilitate the teaching-learning process:

There is no preparation for teachers in Brazil, only in a few undergraduate courses, and most doctors do not know how to teach; they do not even prepare lesson plans (Teacher with 13 years of experience).

I would like teachers in engineering courses to have qualifications for learning methodologies (active or not). Students suffer a lot from the teachers' lack of didactics (Teacher with two years of experience).

The data also reveals that some teachers do not consider necessary training in the didactic-pedagogical area:

I do not consider it essential (Teacher with 35 years of experience). 
The results reinforce that there are still significant opportunities to invest in training for teachers who have just entered the teaching career, but also for experienced ones, fomenting the adoption of newer teaching-learning methods. Moreover, as most entrance teachers have lower academic experience and qualifications (Table 5), Brazilian HEI should foment the promotion of doctoral courses that encompass both technical and pedagogical competences, introducing didactics qualifications.

\subsection{Active Learning}

It was possible to identify that the understanding of the term "active learning" is more related to a personal perception of each respondent than related to a standard definition. About 5.36\% of teachers responded "not aware" in relation to understanding the term "active learning", and 7.32\% did not answer. To support an open-ended question analysis of how teachers (87.32\%) understand active learning, six dimensions related to active learning were used: (I) Student; (II) Autonomy; (III) Questioning reality and reflection; (IV) Teamwork; (V) Innovation; and (VI) Teacher. We highlighted the perceptions of some respondents:

- $\quad$ Student as the center of the teaching-learning process $(25.70 \%)$ :

An education model centered on the student, focusing on learning (Teacher with 45 years of experience).

- $\quad$ Autonomy (34.64\%):

The students have autonomy in their learning (Teacher with 34 years of experience).

- Questioning reality and reflection $(16.76 \%)$ :

Active methodologies use problematization as a teaching-learning strategy, intending to reach and motivate the students because, in the face of the problem, they stop, examine, reflect, relate their story, and start to reframe their discoveries (Teacher with 15 years of experience).

- $\quad$ Teamwork $(3.35 \%)$ :

The situation in which students interact with each other developing the skills to apply what they are learning (Teacher with 14 years of experience).

- Innovation (23.46\%):

Include new methodologies and teaching methods for a better and more dynamic student learning process (Teacher with four years of experience).

- $\quad$ Teacher $(16.20 \%)$ :

The one in which the teacher works as a mediator, developing the student's critical sense, not only as the owner of the "baton", but encouraging, motivating, and guiding the student to search for new knowledge. Develop new forms of teaching and learning where everyone participates (Teacher with 13 years of experience).

From the teachers' perceptions, it appears that they have similar conceptions of active learning to that exposed by the literature, which indicates positive results of the training carried out (Table 9). However, it is worth considering that the respondents tended to be familiar with Engineering Education methodologies and terminologies since they are members of ABENGE. Suppose this study was expanded to non-ABENGE members. In that case, such results could show significant divergences and scenarios of greater conceptual fragility once the sample could comprise respondents who have no contact with studies in Engineering Education, which is still the case with the majority of Brazilian HEI teachers. It is also important to note that teachers' perception, in most cases, involved more than one term (dimension referred above). Additionally, the respondents cited essential aspects of using active learning, as the interaction between teachers and students $(6.14 \%)$, the 
content integration (3.91\%), and the motivation of students $(5.03 \%)$. Some findings from the respondents deserve a highlight:

The educational process, with teacher and student in constant interaction, on the same level (Teacher with three years of experience).

[...] the student must be motivated and oriented to seek knowledge (Teacher with eight years of experience).

Integration of the content discussed in the classroom with practical activities (Teacher with two years of experience).

Concerning the implementation of active learning methodologies in the past three years (2013-2015), about $68.7 \%$ of the teachers said they worked with active learning, strengthening its possible relevance for educators in engineering. Among the methodologies most used by teachers, Table 10 highlights the teamwork activities $(28.8 \%)$; exercise solving (23.9\%); lectures (20.1\%); laboratory (16.9\%); and problem-based learning (16.7\%), followed by project-based learning $(16.3 \%)$. It is important to note that the four methodologies most cited by teachers are not usually identified as active learning approaches.

Table 10. Methodologies used by teachers.

\begin{tabular}{cccccc}
\hline \multirow{2}{*}{$\begin{array}{c}\text { Teaching-Learning } \\
\text { Methodologies }\end{array}$} & Ever & Mostly & Sometimes & Few Times & Never \\
\cline { 2 - 6 } & 16.7 & 25.4 & 37.7 & 15.2 & 5.0 \\
Problem-Based Learning & 6.7 & 12.6 & 42.2 & 20.7 & 17.8 \\
Peer Instruction & 16.3 & 25.2 & 31.1 & 17 & 10.4 \\
Project-Based Learning & 20.1 & 39.6 & 32.4 & 7.9 & 0.0 \\
Lectures & 9.4 & 30.4 & 31.2 & 21.0 & 8.0 \\
Case Studies & 2.2 & 5.2 & 14.8 & 28.1 & 49.6 \\
Games & 16.9 & 25.0 & 31.6 & 16.2 & 10.3 \\
Laboratory & 23.9 & 40.6 & 23.2 & 8.7 & 3.6 \\
Exercise solving & 5.2 & 12.8 & 24.1 & 21.8 & 36.1 \\
Flipped Classroom & 28.8 & 41.7 & 23.7 & 5.8 & 0.0 \\
Teamwork activities & 9.6 & 16.2 & 36.8 & 21.3 & 16.4 \\
Technical visit & 13.2 & 13.2 & 17 & 13.2 & 43.4 \\
Other & & & & \multicolumn{3}{c}{ Frequency (\%) } \\
\hline
\end{tabular}

If, on the one hand, respondents indicate that they favor the use of conventional methodologies, there is still a large number of references belonging to the active learning approaches of games, flipped classroom, and Peer Instruction.

Concerning the main potentialities of active learning for engineering students (Table 11) the respondents identified the motivation as the most relevant factor $(81.4 \%)$, followed by the student approximation to professional practices $(78.6 \%)$, integration of content $(76.4 \%)$, the opportunity for students to develop transversal competences (75.7\%), communication competences $(61.4 \%)$, and the ability to reflect on the professional practice $(59.3 \%)$.

Table 11. Main potentialities of active learning for engineering student training.

\begin{tabular}{cc}
\hline Potentiality & Percentage (\%) \\
\hline Increased motivation for learning & 81.40 \\
Association between theory and practice & 78.60 \\
Content integration & 76.40 \\
Opportunity to develop transversal competences & 75.70 \\
Communication competences & 61.40 \\
Ability to reflect on the professional practice & 59.30 \\
Opportunity for teachers to work collaboratively & 55.00 \\
Enjoy the learning process & 40.00 \\
Other & 10.00 \\
\hline
\end{tabular}


Other potentialities (corresponding to $10 \%$ ) were identified, such as the student's self-empowerment; improving their self-esteem; the tremendous respect to the teacher as a transforming agent; the interaction between student and content in a meaningful way; to the absorption, collaboration feeling in developing the curriculum; the increase in creative abilities of students; effective learning based on student participation in the process; the association between theory and practice; the development of competences and operational abilities (for example, put together a prototype); and the possibility of exercising interpersonal relationships.

The analysis of the results presented in Tables 10 and 11 show that although the respondents know the fundamentals and benefits of active learning, for some reason, they are not applying it as much as they could. This may be caused by a lack of connection between teacher training in active learning practices and the promotion of means for operationalizing the implementation of active learning.

Table 12 represents the difficulties of implementing active learning according to the respondents: the difficulty in engaging students (52.9\%); student insecurity in their own autonomy (51.4\%); higher workload for the teacher $(48.6 \%)$; resource limitations $(45.7 \%)$; the teacher's fear of not covering all the content of the course $(43.6 \%)$; lack of training for dealing with the challenges of implementing active learning methodologies (36.4\%); lack of institutional support (33.6\%); and elaboration of relevant problems and the student's insecurity in the collection and selection of relevant and valuable information, which had an even percentage $(30.7 \%)$.

Table 12. Main difficulties in applying active learning.

\begin{tabular}{|c|c|}
\hline Difficulty & Percentage (\%) \\
\hline Difficulty in getting the student to engage actively & 52.90 \\
\hline Students' insecurity regarding their own autonomy & 51.40 \\
\hline Increased workload for teachers & 48.60 \\
\hline HEI resource limitations & 45.70 \\
\hline The teacher's fear of not covering all the content & 43.60 \\
\hline Lack of training for the challenges of implementing active learning & 36.40 \\
\hline Lack of institutional support & 33.60 \\
\hline Problem design difficulties & 30.70 \\
\hline Students' insecurity in the collection and selection of relevant information & 30.70 \\
\hline Difficulty in clearly understanding the objectives (students) & 24.30 \\
\hline Relationship issues between team members (students) & 16.40 \\
\hline Teacher's frustration by changing their role, reducing the transmission of knowledge & 9.30 \\
\hline
\end{tabular}

Regarding active learning approaches, benefits, and difficulties, it can be highlighted that the most frequent teaching approaches identified by the participants include conventional practices. In spite of participants recognizing the benefits of active learning, namely in terms of student motivation and connection with professional practice, it seems that it is not enough for transforming their practices into more engaging strategies. That is why the analysis of the difficulties is so relevant, allowing us to understand how to prepare teachers for active learning environments. As an example, teachers' training in active learning might include topics related to the preparation of students for active learning.

\subsection{Teachers' Competences for Active Learning}

Regarding the most critical teacher competences for active learning (Figure 1), five competences were most often selected by respondents: teamwork (collaborative work with other teachers, 57.8\%); relation with students (empathy, $49.2 \%$ ); giving feedback throughout the learning process (43.2\%); use of new technologies (39.2\%); selection of methodologies in the teaching and learning process (37.2\%); and creativity (37.2\%). 


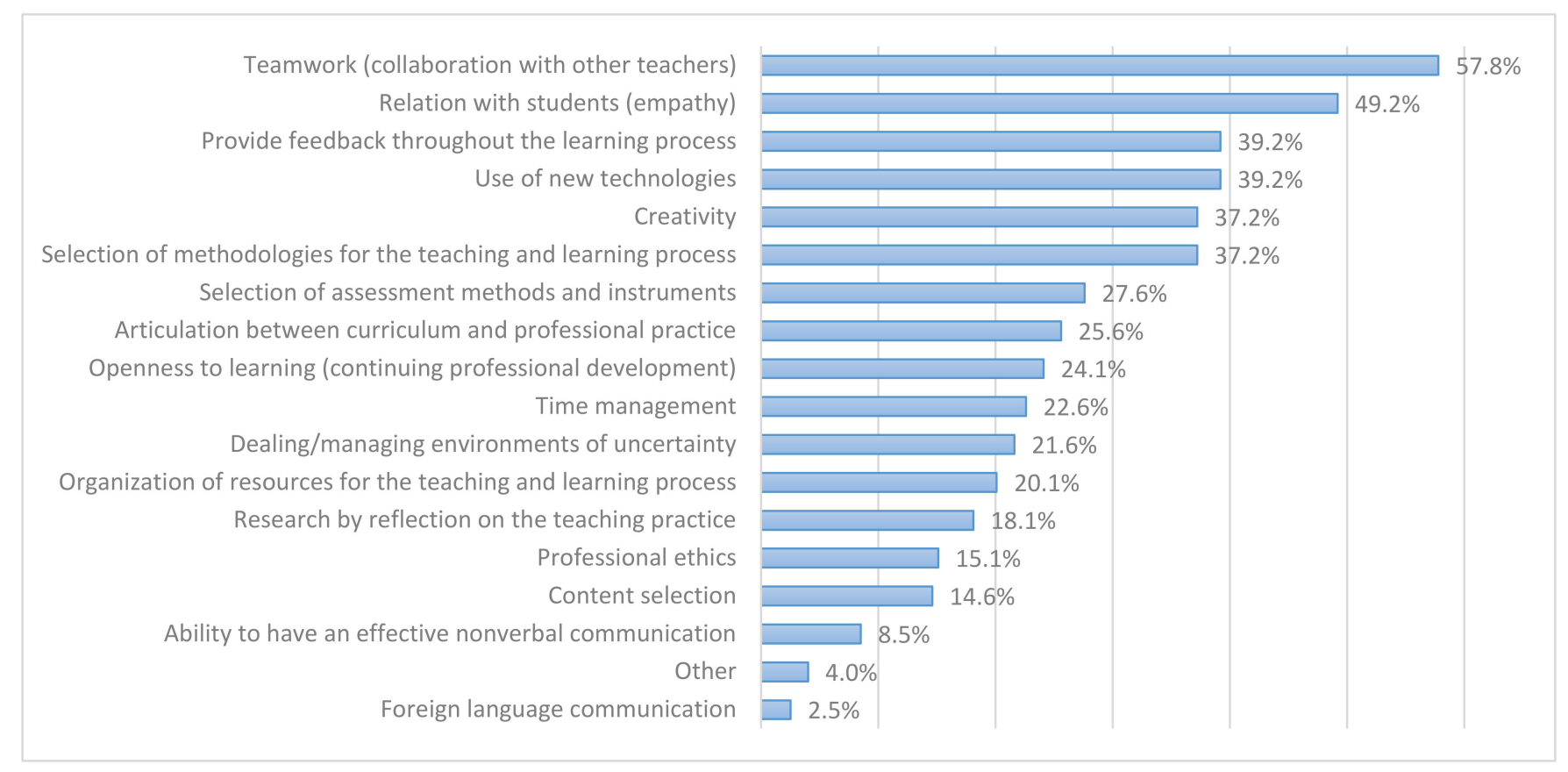

Figure 1. Required teacher competences for implementation of active learning.

It is possible to identify that the competences related to providing feedback throughout the learning process and the selection of adequate methodologies in the teaching-learning process imply pedagogical competences, which demands training and other professional development methods. It reinforces the concern with qualification for teaching once the engineering teachers do not have pedagogical training. In addition to these competences, a deep knowledge of the theme was listed. Some respondents stressed the importance of empathy to develop students' confidence. There is also a concern among some teachers with content compliance and the students' respect for teachers was mentioned, as can be seen in the citations selected from the open-ended questions.

The students [ ... ] are used to mechanized learning-they do not believe in the method and evaluate the teacher poorly-as lazy, for example (Teacher with 13 years of experience).

Content Selection, I will give an example: last semester, I had 130 students divided into three classes. Imagine every period creating several new work proposals that meet the content of the course. Unfortunately, many students will simply copy if the jobs are the same, and we cannot be negligent about it (Teacher with two years of experience).

The teacher needs to be valued. When the students photograph the blackboard, I wonder why they do the same to the fitness facility [ . . . " After I read/study/do it". Nevertheless, there is the myth of distance education! It lacks commitment and decency (Teacher with 25 years of experience).

The teachers' high workload and larger classrooms are also referred to as difficulties in developing active methodologies.

Huge classes and a high teaching workload (Teacher with 31 years of experience).

According to the respondents, teaching competences may be developed through training courses $(50.73 \%)$, personal motivation $(11.71 \%)$, institutional support $(7.31 \%)$, and other $(9.75 \%)$. The proportion of teachers who did not give their opinion was expressive (20.5\%), highlighting a possible difficulty in operationalizing the development of such competences. Although institutional support had a low percentage (almost $8 \%$ ), we can note this is related to training courses (more than $50 \%$ of responses), as seen in some 
respondents' speech. Moreover, other responses referred to the development of these competences through educational projects, educational policies, and guidelines, besides pedagogical practices.

Every higher education institution shall have a core unit of innovation, where some activities would be developed, namely, during the first three months of the teacher recruitment, integration between pedagogical and technical competences. In this integration, the teacher must design the course's curricular matrix, the profiles of each semester, of the course, of the graduate, read the PPC (Pedagogical-Political Curriculum), read the normative program's act, hold workshops on active learning methodologies, assessment by competences, and others (Teacher with two years of experience).

Through the creation of annual weeks for didactic-pedagogical training for teachers. Creation of a training plan. Evaluation of teachers by peers [...] (Teacher with 13 years of experience).

Specific training courses, an educational project of the engineering program concerned with such objectives, enable the teacher to practice and develop it (Teacher with five years of experience).

Concerning the teaching competencies necessary for active learning (Figure 2), the respondents highlighted that the competences could be developed by personal motivation in self-development $(70.5 \%)$, by attending training courses $(60.6 \%)$, by means of a compulsory process $(10.9 \%)$, or with the support of consultancy $(5.7 \%)$.

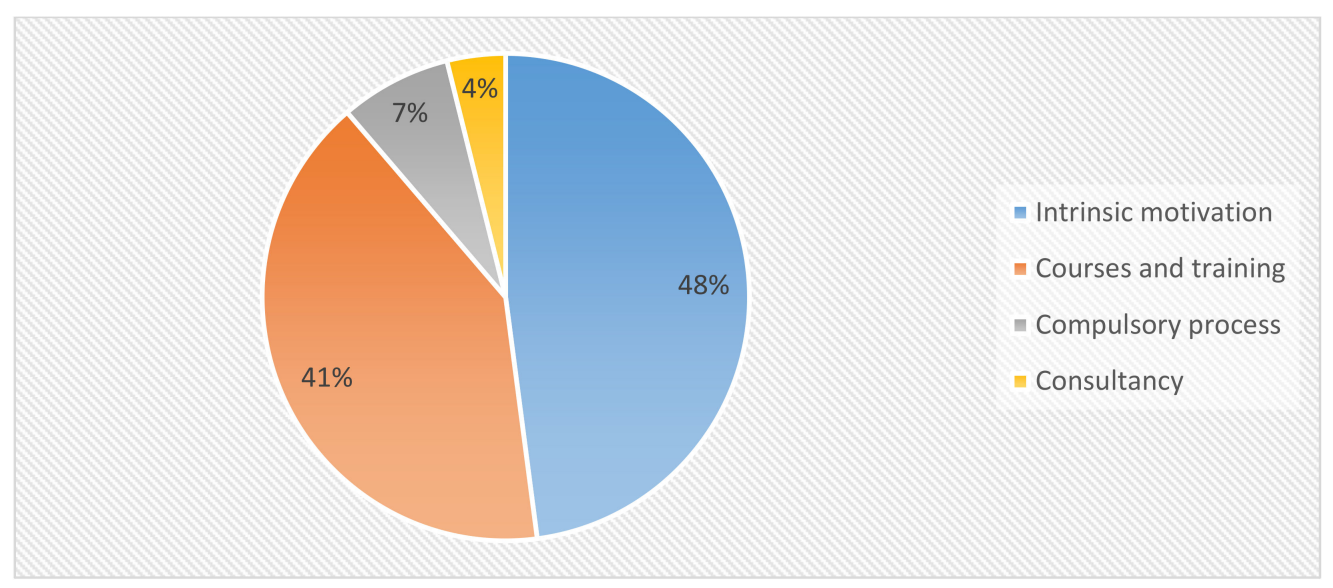

Figure 2. Most effective ways identified by the participants to develop competences for active learning.

The participants in the research also identified alternative means to develop competences for active learning, which are referred in Table 13.

Table 13. Summary of alternative actions to develop competences for active learning.

Alternative Actions
Research and reading.
Voluntary institutional policy to encourage teaching quality.
Working with people with special educational needs.
judgment, and self-confidence.
judroduce practical information to students and support them in developing critical sense,
Moving through other departments of the HEI, including giving extra credits in other subjects to
learn about other methods and interacting with other professors.
Applying the PBL method and publishing articles about it in congresses.




\subsection{Teacher Professional Development}

About $85 \%$ of the sample responded to the item "Opportunities/strategies that should be created or strengthened for the teacher who intends to use active learning methodologies". The answers were grouped into two categories in Table 14: (I) Actions that are the responsibility of the HEI $(81.11 \%)$, and (II) Those with a focus on teachers with a proactive attitude $(16.60 \%)$. The proportion of answers that did not fall into one category or were not relevant to this research represented $2.30 \%$. The HEI-related actions were divided into awareness, training, and qualification (25.80\%); valuing teachers (17.51\%); formal curriculum as materialized in the pedagogic-political project $(16.58 \%)$; infrastructure $(9.22 \%)$; and the interaction between research, extension, and technological innovation $(8.75 \%)$.

Table 14. Actions for working with active learning.

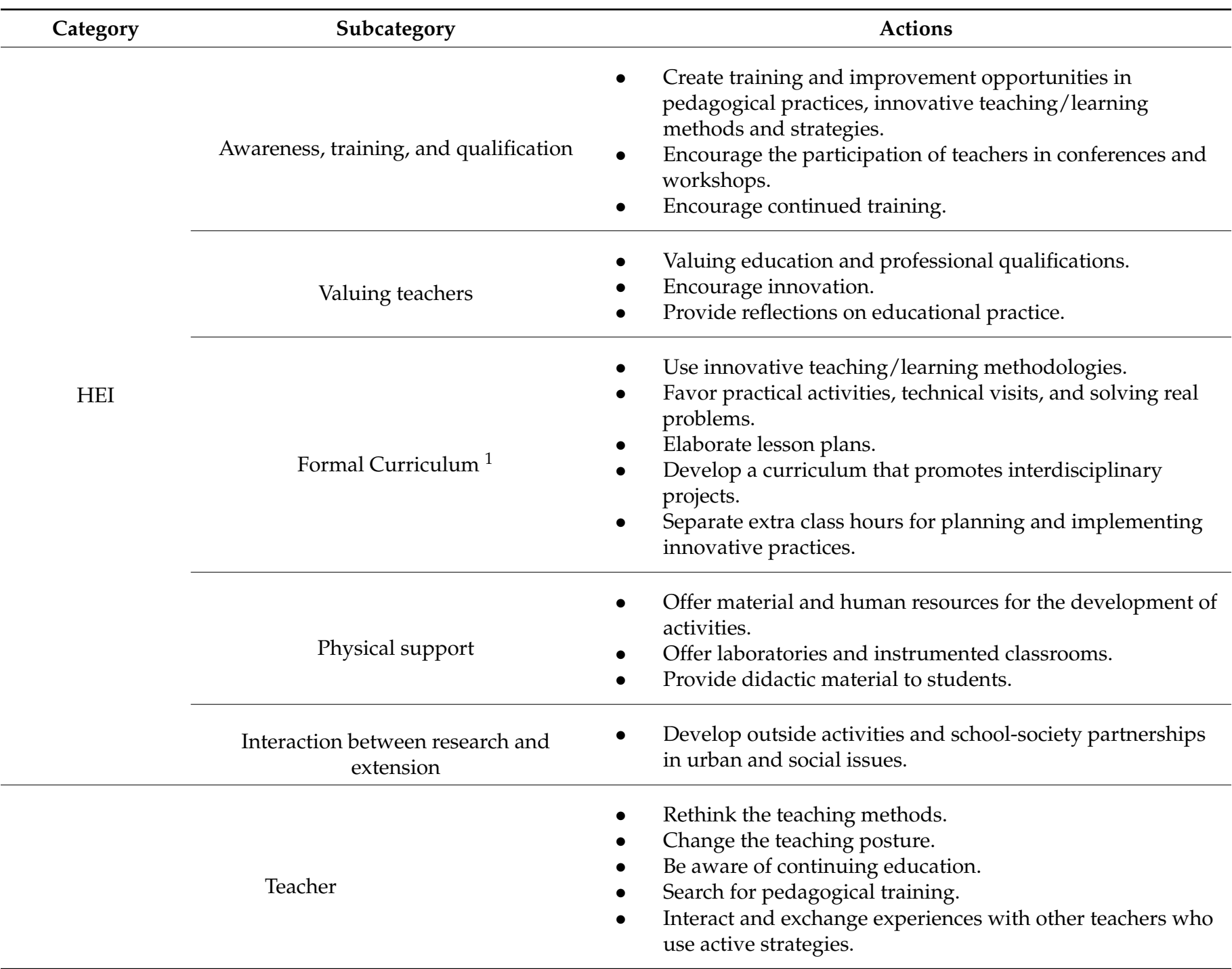

\footnotetext{
${ }^{1}$ It is understood that there are items in other subcategories that are also part of the political, pedagogical project. However, according to the criteria of grouping by keywords, it was executed in this way.
}

As noted in Table 14, the actions are intensely focused on the HEI and development and opportunities/strategies for active methodologies. Thus, it can be noted that the HEI should give importance to awareness, training, and qualification of teachers, to create a functional space to think about the quality of such training, to exchange experiences, and to stimulate the use of new teaching-learning methodologies, aiming at improving the performance of teachers in the classroom. It is also essential to develop strategies that 
encourage and motivate teachers who dedicate both to teaching and research so that they can become multipliers of good teaching practices, stimulating the development of research in teaching.

The formal curriculum is materialized in the political and pedagogical project (PPP), which is a document that directs the planning of actions to the use of active methodologies by the teachers throughout the program's curricular structure. Nevertheless, institutional factors such as the number of students per class and the subjects' integration, among others, according to the teachers' responses, take a special place in difficulties related to the implementation of active learning. The PPP also seeks to apply innovative teachinglearning methodologies, inducing practical activities. Some respondents also identified the need for additional support for the implementation of active learning, including materials, staff, and technological resources. This need could be addressed by creating laboratories/classrooms that encourage active learning. Likewise, the HEIs should favor the interaction between research, extension, and innovation, sharing these experiences in teaching, awakening a more sensitive view of society in future engineers.

Some respondents were more focused on the teacher actions, proposing a search for training and continuing education; creating approaches with a higher connection between theory and practice; development of empathy, and a higher teacher-student interaction.

\subsection{Who Uses Active Learning in Brazilian Engineering Education?}

The logistic regression results (Table 15) correctly predicted $73.4 \%$ of the responses, with significant chi-square value $(26.289, p$-value $=0.000)$. The Hosmer and Lemeshow test indicated the model consistency $(8.653, p$-value $=0.372)$, although the Nagelkerke $\mathrm{R}^{2}$ performed a short overall fit (0.170). It suggests that the implementation of active learning strategies by Brazilian teachers may be related to other variables not comprised in the survey, such as HEI infrastructure, resources, class sizes, student profiles, and other institutional factors out of this research scope.

Table 15. Logistic regression model.

\begin{tabular}{ccccc}
\hline Regressors & B & Exp(B) & Wald & Sig. \\
\hline Gender & & & & - \\
Male $\left(\mathrm{R}^{*}\right)$ & - & - & - & - \\
Female & 0.868 & 2.381 & 5.298 & 0.021 \\
\hline Academic qualification & & & 5.127 & 0.077 \\
Bachelor $\left(\mathrm{R}^{*}\right)$ & - & - & - & - \\
Master's degree & -0.178 & 0.837 & 0.203 & 0.652 \\
Doctorate & -1.014 & 0.363 & 4.663 & 0.031 \\
Workload & & & 5.966 & 0.113 \\
Hourly earner (R*) & - & - & - & - \\
Partial time & 0.032 & 1.033 & 0.003 & 0.955 \\
Full time & 1.138 & 3.120 & 4.279 & 0.039 \\
Full and exclusive time & 0.514 & 1.672 & 0.997 & 0.318 \\
\hline Region & & & 7.095 & 0.131 \\
Southern Brazil (R $\left.{ }^{*}\right)$ & - & - & - & - \\
South-eastern Brazil & 0.978 & 2.659 & 5.999 & 0.014 \\
Middle-Western Brazil & 21.486 & 0.000 & 0.000 & 0.999 \\
North-eastern Brazil & 1.172 & 3.320 & 4.093 & 0.043 \\
Northern Brazil & 0.586 & 1.796 & 0.768 & 0.381 \\
\hline Constant & -0.366 & 0.693 & 0.491 & 0.483 \\
\hline
\end{tabular}

The backward stepwise calculations conducted three rounds, excluding age and experience variables from the final model. It highlights that both senior and beginner teachers can apply active learning strategies, and age or working time seems to be not 
decisive. The final regression form revealed that gender, doctorate diploma, full-time journeys, and south-eastern and north-eastern HEI could statistically differentiate active learning users (at 95\% confidence level).

Regarding gender, considering the participants of this study, female teachers are 2.4 times more likely to employ active learning strategies than male ones. Although more than one-third of the sample are men respondents $(69.3 \%)$, women respondents are strongly oriented to develop active learning.

Academic qualification also predicted a significant outcome. Notice that doctorate members are 0.36 times more likely to develop active learning environments than bachelor ones. While this ratio induces a slight difference among teachers' academic qualifications, it may suggest that higher levels tend to attain faculty members to use other learning processes than the lecture, maybe because they have experienced more teaching and learning processes throughout their career development than the teachers with a bachelor's degree. As an intermediate level, teachers with master's degrees did not perform significant outcomes.

The workload also predicted suitable outcomes. Full-time teachers are 3.12 times more likely to use active learning than hourly earners. This probably occurs due to the more extensive time and financial resources that HEIs dedicate to full-time teachers. Hourly earner teachers tend to maximize their workload in multiple HEIs to provide sufficient wages or divide their journey into professional and academic tasks, lacking time to properly plan active learning courses. Other workload regime teachers did not perform significant outcomes, probably because they have another focus but teaching (as researching in federal institutions), or because they do not think active learning is suitable to their courses-as informed in the survey.

Geographically, south-eastern and north-eastern HEI teachers are 2.6 and 3.3 times more likely to use active learning than the southern ones, respectively. The south-eastern region concentrates almost half $(44.88 \%)$ of the respondents, and it is the main sample of this Engineering Education research. The north-eastern region received an expressive number of HEI since the 2000s, as part of a government attempt to augment higher education offerings to other regions of the country. Northern respondents diverge in the use of active learning strategies, which explain its lack of output significance. The number of middle-western respondents was scarce, which precluded its regression analysis.

\section{Discussion}

This study sought to answer the following question: What are the main teaching competences for active learning, and how to develop those competences to implement active learning? In general, the training of teachers for engineering courses is based on their technical competences, on the practice of their profession, and on the development of core technical research (master's and doctorate in engineering). This aspect reflects how teachers learn the profession of teaching, which generally occurs by trial and error, without formal preparation for teaching life. As a result, there is a teaching-pedagogical gap that tends to create a lack of pedagogical competences, restricting the possibilities of designing and conducting new forms of teaching-learning methodologies.

A new context of a high utilization of a fast-changing technology demands innovative ways to cope with this globalized world in the development of engineering courses. One way to achieve this is by an approximation between theory and practice, and one wonders how the teachers' training is developed in engineering and the consequences of a wellknown deficient pedagogical development of higher education teachers in general. When implementing innovative teaching-learning methodologies, the challenge encountered by teachers is summarily associated with the uncertainty of developing the content in practice, how to mediate this new context in which the teacher is involved in both the process of teaching and learning. Active learning requires the need for teachers to be highly prepared, both from technical and pedagogical points of view. 
In this regard, teachers tend to develop active learning approaches without relevant competences, seeing themselves forced to develop competences that were not previously stimulated throughout their professional formation. Then, one wonder how teachers can develop active learning methodologies if their training trajectory was exclusively based on conventional (and opposite) methodologies? How can students be taught learning to learn if the educators have inherent difficulties in defining and operationalizing active learning, partly due to their experience as students and partly due to their lack of training when entering their teaching profession in higher education?

\section{Conclusions}

It is relevant for sustainable Engineering Education to design organizational initiatives that contribute to the development of teacher competences for implementing active learning environments. Based on the participants in this study, five main teacher competences should be developed in the context of active learning: (I) teamwork (cooperative work with others); (II) teacher-student relationship (empathy); (III) providing feedback throughout the learning process; (IV) use of new technologies; and (V) selection of teaching-learning methodologies. From these, it is clearly understood that teachers are not only knowledge transmitters. Instead, they need to give autonomy to the students aiming at deepening their learning. For that, they need to motivate the students. Therefore, besides being competent in technical and professional issues, the teacher needs to have pedagogical competences. In addition to teachers' intrinsic motivation to work in this context of active learning, educational institutions must have periodic training plans for teachers to develop those competences. For this, it is essential to discuss the pedagogical training among the professor in engineering courses.

At this COVID-19 pandemic moment, teacher training and active-learning competences are even more important to face the emergency transformation for online and blended approaches, in very different personal and institutional contexts of all stakeholders. It created high stress in rethinking content, resources and methods used, in a real-time transformation of the communication process, trying to reduce the teacher-student distance. Digital resources, innovation, creativity, and mental and psychological control are essential for teachers to adapt to this new context. As noted in our results, it is vital that the teacher, through reflection and personal motivation, seeks to develop their pedagogical competences to develop teaching strategies and methodologies that simultaneously seek to consolidate students' learning and establish working conditions that add quality to the education of engineers, and personal satisfaction to the teacher. Such developments are essential because they foment more efficient and healthy educational environments. Finally, development of new research is necessary and relevant to understand the continuing, changing needs for teacher training in this new world that mix face-to-face, online, and hybrid education environments.

Author Contributions: Conceptualization, R.M.N. and R.M.L.; methodology, R.M.N., R.M.L., and D.M.; internal validation, R.M.L. and D.M.; analysis, R.M.N., R.M.L., and D.M.; research, R.M.N.; data curation, R.M.N.; writing — original draft preparation, R.M.N.; writing—reviewing and editing, R.M.N., R.M.L., and D.M.; funding acquisition, R.M.N. and R.M.L. All authors have read and agreed to the published version of the manuscript.

Funding: This research was funded by the Brazilian National Council for Scientific and Technological Development (CNPq), grant number 205430/2014-7. This work was partially supported by FCTFundação para a Ciência e Tecnologia within the R\&D Units Project Scope UIDB/00319/2020.

Institutional Review Board Statement: Ethical review and approval were waived for this study due to the questionnaire examination by experts, who also assessed the ethical statements.

Informed Consent Statement: Respondents' consent - informed consent was obtained from all subjects involved in the study. 
Data Availability Statement: The questionnaire data are available from the corresponding author upon reasonable request.

Acknowledgments: We thank all respondents for supporting the questionnaire application, as well as the Engineering Education specialists who were essential for developing the final revised and improved questionnaire.

Conflicts of Interest: The authors declare no conflict of interest.

\section{Appendix A}

This appendix describes some specific items (translated from Brazilian Portuguese) of the questionnaire used in this research. The questionnaire has four main parts. Parts 1 and 2 are related to the characterization of the participants, the first being related to gender, age, and academic qualifications. The second part is related to information about being a teacher in Higher Education: the qualifications when entering the career; years of experience; work regime dedication; country state and region; and finally, there were questions about participation in training, if yes, then what, and if not, then why.

The third part is related to active learning, starting with an open-ended question about the meaning of active learning, followed by a question asking if the teacher implemented active learning in the previous 3 years. If the teacher answered that he/she has implemented active learning, then he/she is asked about the frequency (never, rarely, sometimes, most often, always) of implementation of several approaches, including some that are not usually included in active learning. The list used in the questionnaire was the following:

- $\quad$ Problem-Based Learning (PBL)

- $\quad$ Project-Based Learning (PBL)

- Peer Instruction

- Lectures

- $\quad$ Case Study

- Games

- Laboratory

- $\quad$ Exercise solving

- $\quad$ Flipped Classroom

- Teamwork activities

- $\quad$ Technical Visit

- $\quad$ Other (open-ended question)

The next question in this part is related to the main potential of active learning for training engineers, and the participants could check all that apply from the following list:

- Opportunity for students to develop transversal competences

- Content integration

- $\quad$ Ability to reflect on the professional practice

- Opportunity for teachers to work collaboratively

- Communication competences

- Increased motivation for learning

- Association between theory and practice

- $\quad$ Enjoy the learning process

- $\quad$ Other (open-ended question)

The next question in this part is related to the main difficulties of implementing active learning, and the participants could check all that apply from the following list:

- $\quad$ Lack of institutional support

- Difficulty in getting the student to engage actively

- Teacher's frustration by changing their role, reducing the transmission of knowledge

- HEI resource limitations

- Students' insecurity regarding their own autonomy

- $\quad$ Problem design difficulties 
- $\quad$ Lack of training for the challenges of implementing active learning

- Relationship issues between team members (students)

- Difficulty in clearly understanding the objectives (students)

- Increased workload for teachers

- The teacher's fear of not covering all the content

- Students' insecurity in the collection and selection of relevant information

- Other (open-ended question)

Part four is dedicated to the teacher competences, starting by a selection of the five most important teaching competences for active learning from the following list:

- $\quad$ Relation with students (empathy)

- $\quad$ Provide feedback throughout the learning process

- $\quad$ Ability to have an effective nonverbal communication

- Communication in a foreign language

- Teamwork (collaboration with other teachers)

- Research by reflection on the teaching practice

- Professional ethics

- Use of new technologies

- Content Selection

- Organization of resources for the teaching and learning process

- Selection of methodologies for the teaching and learning process

- Selection of assessment methods and instruments

- Articulation between curriculum and professional practice

- $\quad$ Time management

- Creativity

- Dealing/managing environments of uncertainty

- Openness to learning (continuing professional development)

- Other (open-ended question)

After selecting the most important competences, the participant is asked, in his/her own point of view, to explain how these competences can be developed by teachers, and how she/he developed those competences. Finally, the questionnaire has the following three open-ended questions:

- What opportunities/strategies should be created/strengthened for the teacher who wishes to use active learning?

- What is your view of the Engineering teacher within 10 years?

- Do you have any additional comments or suggestions?

\section{References}

1. United Nations Educational, Scientific and Cultural Organization. Engineering: Issues, Challenges and Opportunities for Development. Published in 2010 by the United Nations Educational, Scientific and Cultural Organization. Available online: http:/ / unesdoc.unesco.org/images/0018/001897/189753e.pdf (accessed on 17 May 2021).

2. Lima, R.M.; Dinis-Carvalho, J.; Sousa, R.M.; Arezes, P.; Mesquita, D. Development of competences while solving real industrial interdisciplinary problems: A successful cooperation with industry. Production 2017, 27, e20162300. [CrossRef]

3. Fernandes, S.; Mesquita, D.; Flores, A.M.; Lima, R.M. Engaging students in learning: Findings from a study of project-led education. Eur. J. Eng. Educ. 2014, 39, 55-67. [CrossRef]

4. De Graaff, E.; Kolmos, A. Characteristics of Problem-Based Learning. Int. J. Eng. Educ. 2003, 19, 657-662.

5. Freeman, S.; Eddy, S.L.; McDonough, M.; Smith, M.K.; Okoroafor, N.; Jordt, H.; Wenderoth, M.P. Active learning increases student performance in science, engineering, and mathematics. Proc. Natl. Acad. Sci. USA 2014, 111, 8410-8415. [CrossRef]

6. Goldberg, D.; Sommerville, M. A Whole New Engineer-The Coming Revolution in Engineering Education; Threejoy Associates: Douglas, Michigan, USA, 2014.

7. Haith-Cooper, M. Problem-based learning within health professional education. What is the role of the lecturer? A review of the literature. Nurse Educ. Today 2000, 20, 267-272. [CrossRef]

8. Cordeiro, J.S.; Almeida, N.N.; Borges, M.N.; Dutra, S.C.; Valinote, O.L.; Martin, Z.C.P. Um futuro para a educação em engenharia no Brasil: Desafios e oportunidades. Rev. Ensino Eng. 2008, 27, 69-82. [CrossRef]

9. Zabalza, M.A. O Ensino universitário [recurso eletrônico]: Seu cenário e seus protagonistas; Artmed: Porto Alegre, Brazil, 2007. 
10. Oliveira, J.A.C.B.; Pinto, G.R.P.R.; Santos, J.M.J. Uso de Estratégias Ativas na Educação em Engenharia no Brasil: Um mapeamento sistemático de experiências a partir das publicações realizadas no COBENGE. In Proceedings of the Congresso Brasileiro de Ensino de Engenharia, UDESC, Joinville, Brazil, 23-26 June 2017.

11. Prince, M. Does Active Learning Work? A Review of the Research. J. Eng. Educ. 2004, 93, 223-231. [CrossRef]

12. Bonwell, C.C.; Eison, J.A. Active Learning: Creating Excitement in the Classroom; ASHE-ERIC Higher Education Reports: Washington, DC, USA, 1991; Volume 1.

13. Gudwin, R.; Aprendizagem, A. Available online: https://faculty.dca.fee.unicamp.br/gudwin/activelearning (accessed on 17 May 2021).

14. Pereira, C.F.; Afonso, R.A.; Santos, M.J.; Araújo, C.A.L.; Nogueira, A.M. Aprendizagem baseada em problemas (ABP)—Uma proposta inovadora para os cursos de engenharia. In Proceedings of the XIV SIMEP; University of the Paulista State, Bauru, Brazil, 5-7 November 2007.

15. Diesel, A.; Baldez, A.L.S.; Martins, S.N. Os princípios das metodologias ativas de ensino: Uma abordagem teórica. Rev. Thema 2017, 14, 268-288. [CrossRef]

16. Christie, M.; De Graaff, E. The philosophical and pedagogical underpinnings of Active Learning in Engineering Education. Eur. J. Eng. Educ. 2017, 42, 5-16. [CrossRef]

17. Ramirez-Mendoza, R.A.; Morales-Menendez, R.; Melchor-Martinez, E.M.; Iqbal, H.M.N.; Parra-Arroyo, L.; Vargas-Martínez, A.; Parra-Saldivar, R. Incorporating the sustainable development goals in engineering education. Int. J. Interact. Des. Manuf. 2020, 14, 739-745. [CrossRef]

18. Guerra, A. Integration of sustainability in engineering education. Int. J. Sustain. Higher Educ. 2017, 18, 436-454. [CrossRef]

19. Huntzinger, D.N.; Hutchins, M.J.; Gierke, J.S.; Sutherland, J.W. Enabling sustainable thinking in undergraduate engineering education. Int. J. Eng. Educ. 2007, 23, 218-230.

20. Taheri, P. Project-based approach in a first-year engineering course to promote project management and sustainability. Int. J. Eng. Pedag. 2018, 8, 104-119. [CrossRef]

21. Terrón-López, M.-J.; Velasco-Quintana, P.J.; Lavado-Anguera, S.; de Espinosa-Elvira, M.C. Preparing Sustainable Engineers: A Project-Based Learning Experience in Logistics with Refugee Camps. Sustainability 2020, 12, 4817. [CrossRef]

22. Tsinajinie, G.; Kirboyun, S.; Hong, S. An Outdoor Project-Based Learning Program: Strategic Support and the Roles of Students with Visual Impairments Interested in STEM. J. Sci. Educ. Technol. 2021, 30, 74-86. [CrossRef]

23. Peixoto, A.; González, C.S.G.; Strachan, R.; Plaza, P.; de los Angeles Martinez, M.; Blazquez, M.; Castro, M. Diversity and inclusion in engineering education: Looking through the gender question. In Proceedings of the 2018 IEEE Global Engineering Education Conference (EDUCON), Santa Cruz de Tenerife, Spain, 17-20 April 2018; pp. 2071-2075. [CrossRef]

24. Cuzzuol, G.D.; Campos, L.B.P.; Mesquita, D.; Lima, R.M. Collaborative PBL to Teach Calculus to Engineering Students: The Important Role of Collaborative Professors. Int. J. Eng. Educ. 2019, 35, 1456-1465.

25. Chan, M.M.; Blikstein, P. Exploring Problem-Based Learning for Middle School Design and Engineering Education in Digital Fabrication Laboratories. Interdiscip. J. Problem Based Learn. 2018, 12, 7. [CrossRef]

26. Taheri, P.; Robbins, P.; Maalej, S. Makerspaces in First-Year Engineering Education. Educ. Sci. 2020, 10, 8. [CrossRef]

27. Coronado, J.M.; Moyano, A.; Romero, V.; Ruiz, R.; Rodríguez, J. Student Long-Term Perception of Project-Based Learning in Civil Engineering Education: An 18-Year Ex-Post Assessment. Sustainability 2021, 13, 1949. [CrossRef]

28. Guasch, T.; Alvarez, I.; Espasa, A. University teacher competencies in a virtual teaching/learning environment: Analysis of a teacher training experience. Teach. Teach. Educ. 2010, 26, 199-206. [CrossRef]

29. Bardía, R.B. Las competencias del profesorado en el entorno CDIO. REDU Rev. Docência Univ. 2012, 10, 57-73. [CrossRef]

30. Panev, V.; Barakoska, A. The need of strengthening the pedagogical competencies in teaching from the english teachers' perspective. Int. J. Cogn. Res. Sci. Eng. Educ. 2015, 3, 43-50. [CrossRef]

31. Shankar, S.; Gowtham, N.; Surekha, T.P. Faculty competency framework: Towards a better learning profession. Procedia Comput. Sci. 2020, 172, 357-363. [CrossRef]

32. Cargnin-Stieler, M.; Teixeira, M.C.M.; Lima, R.M.; Mesquita, D.; Assunção, E. A Contribution for the Analysis of Pedagogical Training for Teaching in Electrical Engineering. Int. J. Contin. Eng. Educ. Life-Long Learn. 2016, 26, 405-418. [CrossRef]

33. Akhmetova, J.B.; Kim, A.M.; Harnisch, D.L. Using Mixed Methods to Study Emotional Intelligence and Teaching Competencies in Higher Education. Procedia Soc. Behav. Sci. 2014, 128, 516-521. [CrossRef]

34. Perea, E.C. Competencias para la tutoría: Experiencia de formación con profesores universitarios. REDU Rev. Docência Univ. 2012, 10, 193-210. [CrossRef]

35. Oliva, A.D.-J.; Fernández, A.D. Empleo de los medios sociales en educación superior: Una nueva competencia docente en ciernes. REDU Rev. Docência Univ. 2012, 10, 365-379. [CrossRef]

36. Pantić, N.; Wubbels, T. Teacher competencies as a basis for teacher education-Views of Serbian teachers and teacher educators. Teach. Teach. Educ. 2010, 26, 694-703. [CrossRef]

37. Bitlloch, T. Identificación de competencias docentes que orienten el desarrollo de planes de formación dirigidos a profesorado universitario. REDU Rev. Docência Univ. 2012, 10, 21-56. [CrossRef]

38. Valle, A.R.A.; García, C.B.; Ubieto-Artur, M.I.; Cebrián, M.D.M.; Díaz, S.S.; Noguera, H.J.; Costa, T.P. Competencias del buen docente universitario. Opinión de los estudiantes. REDU Rev. Docência Univ. 2015, 13, 363-390. [CrossRef] 
39. Yu, J.H.; Luo, Y.; Sun, Y.; Johannes, S. A Conceptual K-6 Teacher Competency Model for Teaching Engineering. Procedia Soc. Behav. Sci. 2012, 56, 243-252. [CrossRef]

40. König, J.; Jäger-Biela, D.J.; Glutsch, N. Adapting to online teaching during COVID-19 school closure: Teacher education and teacher competence effects among early career teachers in Germany. Eur. J. Teach. Educ. 2020, 43, 608-622. [CrossRef]

41. Bringhenti, I. O Ensino na Escola Politécnica da USP: Fundamentos para o Ensino de Engenharia; EPUSP: São Paulo, Brazil, 1993.

42. Neves, R.M. Das modelo de capacitação de gerentes intermediários na construção civil baseado na ABP; Federal University of Rio Grande do Sul: Porto Alegre, Brazil, 2005.

43. Lima, R.M.; Carvalho, D.; Sousa, R.M.; Alves, A.; Moreira, F.; Mesquita, D.; Fernandes, S. A Project Management Framework for Planning and Executing Interdisciplinary Learning Projects in Engineering Education. In Project Approaches to Learning in Engineering Education; Sense Publishers: Rotterdam, The Netherlands, 2012.

44. Vasconcelos, M.L.M.C. A Formação de Professor do Ensino Superior; Xamã: São Paulo, Brazil, 2009.

45. Masetto, M.T. Competência Pedagógica do Professor Universitário, 4th ed.; Sammus: São Paulo, Brazil, 2003.

46. Pereira, A.S.; Shitsuka, D.M.; Parreira, F.J.; Shitsuka, R. Metodologia da Pesquisa Científica, 1st ed.; UAB/NTE/UFSM: Santa Maria, CA, USA, 2018.

47. Cleff, T. Applied Statistics and Multivariate Data Analysis for Business and Economics: A Modern Approach Using SPSS, Stata, and Excel, 1st ed.; Springer: New York, NY, USA, 2019.

48. Field, A. Discovering Statistics with SPSS, 5th ed.; Sage Publications: New York, NY, USA, 2017. 